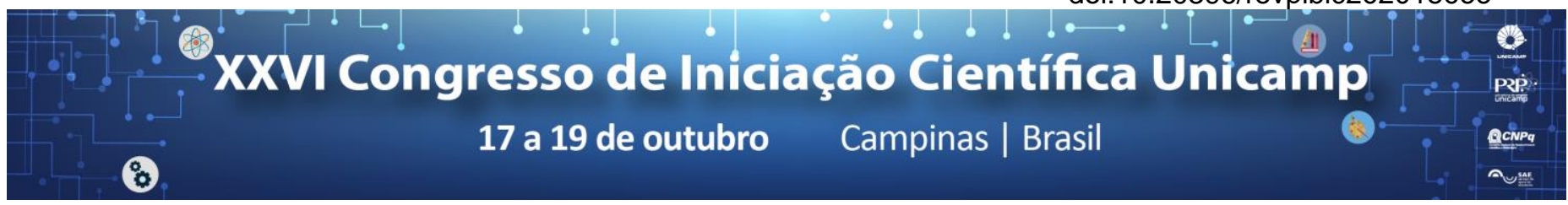

\title{
Induced seed dispersal of Cecropia hololeuca (Urticaceae) by birds and mammals in a restored area at APA Campinas, Campinas - SP
}

\author{
Jasmim F. de Oliveira, Wesley R. Silva.
}

\begin{abstract}
Seed dispersal is an important natural process in the restoration of degraded ecosystems. The aim of this project is to identify the frugivorous fauna with potential for the induced dispersal of Cecropia hololeuca (Urticaceae) seeds, immersed in banana pulp and offered in a feeder located in a restored area, and to evaluate its role in the enrichment of this area. The frugivorous species visiting the feeder were filmed by self-firing cameras and their behavior were analyzed in relation to the frequency of occurrence and their relative efficiency in the dispersal of these seeds. The marmoset Callithrix penicillata showed the greatest dispersive potential, despite being an invasive species.
\end{abstract}

\section{Key words: \\ Frugivory, restoration, Cecropia}

\section{Introduction}

Seed dispersal is an important evolutionary mechanism of angiosperms ${ }^{1}$. The understanding of this process is of great relevance for the restoration of degraded ecosystems, especially when low cost methods are involved $^{2}$. The aim of this project is to identify the frugivorous fauna with potential for the induced dispersal of Cecropia hololeuca (Urticaceae) seeds, immersed in commercial banana pulp, offered in a feeder located in a restored area in the APA Campinas, and to evaluate its role in the enrichment of this area.

\section{Results and Discussion}

The frugivorous species visiting the feeder were filmed by self-firing cameras and their behavior were analyzed in relation to the frequency of occurrence, as well as their relative efficiency in the dispersal of these seeds. It is expected that the evaluation of birds and mammals as restoration tools through the induced seed dispersal will represent an alternative and efficient technique for the enrichment of restoration sites.

The Black-tufted marmoset Callithrix penicillata was the most frequent species in the video sequences (Table 1), with more individuals per sequence, but with the lowest latency time, that is, with the lowest interval between the placement of the bananas and the arrival of the species at the feeder. Visits were more frequent when bananas were available at the feeder, than when they were absent. The big-eared opossum Didelphis aurita was the second more frequent species at the feeder, although visiting the feeder more frequently when no bananas were available.

The consumption and the bite rate of $C$. penicillata was higher than that of D. aurita. Furthermore, the marmosets visited the feeder in small groups of up to 10 individuals, while the opossum visited the feeder individually. A collective feeding pattern is considered more efficient for the induced seed dispersal of Cecropia hololeuca, once the more seeds are dispersed better the chance of survival of the seeds ${ }^{3}$.
Table 1. Total time and percentage of records per species in the video sequences taken at the feeder.

\begin{tabular}{|l|r|r|}
\hline \multicolumn{1}{|c|}{ Species } & Hours & Percentage \\
\hline Callithrix penicillata & 21.49 & $81.81 \%$ \\
\hline Didelphis aurita & 3.78 & $14.40 \%$ \\
\hline Turdus amaurochalinus & 0.63 & $2.39 \%$ \\
\hline Cyanocorax cristatellus & 0.19 & $0.72 \%$ \\
\hline Turdus leucomelas & 0.13 & $0.51 \%$ \\
\hline Eira barbara & 0.04 & $0.15 \%$ \\
\hline Tachyphonus coronatus & 0.01 & $0.02 \%$ \\
\hline Total & $\mathbf{2 6 . 2 7}$ & $\mathbf{1 0 0} \%$ \\
\hline
\end{tabular}

\section{Conclusions}

Callithrix penicillata seems to have the greatest dispersal potential among the frugivores in the studied community. Although it is currently an invasive primate species in the Atlantic Forest of southeast Brazil, the results indicate that it can effectivelly be an important disperser agent in the enrichment of restored areas through the technique of induced seed dispersal, especially when small seeds are being introduced in these areas.

\section{Acknowledgement}

This study was supported by FAPESP (Grant 2017/11310-1). We are grateful to the Laboratório de Interações Vertebrados-Plantas, UNICAMP, for the institutional suport, and to the Guariroba Farm for the permission to work there. We also thank Cristiane Zaniratto, Diego Casallas, José Otávio Venancio and Maria Elisa Morandi who assisted in field and laboratory work.

${ }^{1}$ Begon, M.; Harper, J. L. and Townsend, C. R. Ecologia: De Indivíduos a Ecossistemas. $4^{\mathrm{a}}$ edição. Editora Artmed, 2007.

${ }^{2}$ Reis, A.; Zambonim, R. M. and Nakazono, E.M. Recuperação de áreas florestais degradadas utilizando a sucessão e as interações planta-animal. São Paulo: Conselho Nacional da Reserva da Biosfera da Mata Atlântica. Série Cadernos da Reserva da Biosfera da Mata Atlântica, 1999, n. 14, 42.

${ }^{3}$ Pizo, M. A. and Simão, I. Seed deposition patterns and the survival of seeds and seedlings of the palm Euterpe edulis. Acta Oecologica, 2001, 22.4, 229233. 